\title{
PERFECTING THE CONDOMINIUM AS A HOUSING TOOL: INNOVATIONS IN TORT LIABILITY AND INSURANCE
}

\author{
Patrick J. Rohan*
}

INTRODUCTION

Housing discussions frequently center around "suburban sprawl" and the city's effort to combat neighborhood decline, originate and maintain low and middle income housing, and meet population pressures with high-rise commercial, apartment, and multipurpose buildings. The condominium concept, virtually unheard of five years ago, may soon see service in all of these areas. Thus, for example, it has been heralded as a means of restoring the amenities of city living, as well as the ideal format for suburban property owner associations. More recently, public officials have begun to explore its potential as a source of "home ownership" for economically deprived families. Whatever the relative merits of these projections, condominiums now constitute a significant percentage of all new housing starts and must figure prominently in the thinking of land planners.

Enabling acts, designed to provide a legislative foundation for the condominium format and to fit it into the existing legal system, have been enacted by the federal government, District of Columbia, and forty-nine states. ${ }^{1}$ However, perfection should not be anticipated in such a broad undertaking; drafting flaws are certain to appear as experience is gained with various condominium uses. One such imperfection has recently come to the writer's attention, namely, failure to clarify the unit owner's posture (and that of his household) with respect to tort liability and insurance. What is the nature and extent of the risk assumed as co-owner of the project and its facilities? What policies are available to neutralize this exposure and should protection be purchased on an individual or community basis, or perhaps both? Conversely, is a participant permitted to sue the group (or a fellow unit owner) if negligently harmed? Would such a judgment be covered by a master liability policy? While these and related queries may have been academic in other times and societies, the omnipresence of insurance and today's tort calendars indicate that these questions will press for immediate resolution. As might be anticipated, some unit owners have already fallen on icy, commonly-owned walks or met with other mishaps. Counsel

* B.A. I954, LL.B. 1956, St John's University; LL.M. 1957, Harvard University; J.S.D. 1965, Columbia University. Professor of Law, St. John's University. Co-author [with M. A. Reskin], Condominium Law and Practice (1965); Cooperative Housing: Law and Practice (1967); Revision Editor, R. Poweli, Real Property.

The writer wishes to acknowledge the research assistance and valuable insights he received from Thomas G. Cody, Esq., of New York.

${ }^{2}$ At this writing, Vermont, the only state without a condominium statute, has an cnabling act pending in its legislature. 
for insurance carriers grappling with their complaints are finding scant, if any, authority upon which to base an opinion. In the pages which follow, an attempt is made to resolve these uncertainties and to indicate what remedial steps should be taken by the various state legislatures and insurance departments.

\section{The Case for Explicit Treatment}

Some may object to the assertion that tort liability and insurance should be treated in the enabling legislation (or ancilliary regulations), on the ground that these are matters of detail best left to the individual project's draftsman. While such a laissez-faire attitude currently holds sway, a persuasive case can be made for the proposition that direction, if not uniformity, should be supplied at the legislative or administrative level.

\section{A. The Desideratum of Certainty}

Real property laws and procedures have always placed a premium on certainty, for obvious reasons. Condominium projects will have to find that ingredient in either the enabling act or precedents governing concurrent ownership. But condominium statutes are largely silent on tort liability and insurance, and common law treatments are fragmentary at best. Also to be considered is the question whether a condominium statute pre-empts the field, in which event answers would have to be found in oblique legislative passages which were never intended to be controlling. In view of the foregoing, it is doubtful that project draftsmen and attorneys for unit owners can safely state what their clients' rights and obligations are, and what insurance coverage is appropriate. Further, it is not clear that declaration and by-law provisions on this subject would be enforceable. For example, may a project's documentation bar the unit owner's cause of action in negligence or exonerate management for all but willful wrongs? From the long-range viewpoint, uncertainty (or worse, resolution of doubts against the unit owner), might undermine public confidence in condominiums and permanently impair their development. Just such a progression of events led to the demise of syndications as a real estate investment vehicle.

\section{B. The Danger of Improper Insurance Coverage}

It is obvious that carriers were not writing liability policies for condominiums (and their constituent owners) prior to IgGI, the date of the first legislative activity in the field. Again, no policy then in existence could fit the needs of the condominium, in view of the many uses to which the concept may be put and its peculiar legal structure. Accordingly, it is highly probable that traditional policies will result in duplication of coverage in some instances (as between individual and group insurance), as well as inadequate coverage in others. Similarly, unit and master policies may conflict or bring about troublesome subrogation disputes. A question 
may also arise as to whether such insurance covers contractual obligations, binding the unit owners to indemnify the board of managers and managing agent. In short, an adequate insurance program is not guaranteed by large premium payments and still larger policy limits. Both condominium unit owners and injured parties would be rendered a disservice if foreseeable risks were not covered, despite sizable premium expenditures. The conclusion appears inescapable that standard condominium liability policies should be drawn up, to provide unit owners with maximum protection for their insurance dollar.

\section{The Absence of Litigation and Judgment Execution Guidelines}

Several enabling acts contain procedures for processing contractual claims against the condominium association, including detailed steps for collecting these judgments. ${ }^{2}$ However, scant attention has been paid to the quantitatively more significant area of tort actions and judgments. In the absence of such directions, counsel for an injured party may take the safest route-that is, serve everyone who might be a necessary or proper party. If this became the practice, any tort claim touching the condominium in any way would result in a suit against the condominium association, the board of managers, managing agent, and all unit owners. Serious problems of title would also ensue, if a judgment resulted in joint and several liability; once docketed, no unit could be sold without placing in escrow the full amount of the judgment, with interest. In a similar vein, what would be the status of unit owners (and of their respective titles), between the time the judgment was rendered and the time the association voted to assess its members to pay it? Many more illustrations may be supplied, but the cited hypotheticals are sufficient to indicate the wisdom of codifying rules governing tort litigation and enforcement of resulting judgments.

\section{The Unit Owner as Plaintiff}

Perhaps the most troublesome question in this entire area is whether a unit owner may sue a fellow participant or the group itself. Thus, for example, may unit owner $A$ sue owner $B$ (or the condominium association) in a case where $A$ falls over an object left in a common hall by $B$ ? May $A$ sue the group if he is injured in an elevator mishap or through the negligence of maintenance personnel? What if he were injured in a garage or restaurant owned or operated by the association? If $A$ 's suit is barred, would the same result be forthcoming in the event a member of $A$ 's family (or his servant) met with a similar mishap? If the capacity-to-sue hurdle is overcome, would such judgments be collectible from the association's carrier under the master liability policy, or would this exposure be uninsured?

It cannot be seriously contended that these matters should be worked out on a project-by-project basis, or under the auspices of local carriers. These issues go to the essence of the condominium unit owner's bundle of rights and obligations. Should

\footnotetext{
${ }^{3}$ E.g., N.Y. ReAI Prop. LAW $\$ 339-l$ (McKinney Supp. 1967).
} 
there not be a legislative determination as to whom a unit owner may sue in negligence, especially if the conclusion reached is that he cannot sue? Conversely, if such suits are authorized, should there not be a directive as to the contents of master policies in this regard, for the parties most likely to suffer injury in a condominium development are its occupants. There may even be a conflict of interest here. Neither the original draftsman nor insurance carrier will become a unit owner, and both have a motive for keeping insurance costs down: one to minimize carrying charges and sell units, the other to secure the insurance business. Lastly, there is serious question whether private controls along these lines would be against public policy, absent specific legislative sanction. For these reasons, the capacity to sue issue should be resolved authoritatively and on a statewide basis.

\section{II}

\section{UnIT OwNER LIABIIITY}

\section{A. The Prevailing Pattern}

As previously noted, most condominium statutes are silent on the nature and extent of a unit owner's non-contractual liability. Legal observers therefore conclude that, as co-owners, participants would be jointly and severally liable for tortious conduct in connection with the project. ${ }^{3}$ Condominium authorities abroad hold to the same view. ${ }^{4}$ The full impact of this conclusion is difficult to grasp, until one lists the conceivable sources of liability. A partial list would include:

r. Failure to maintain common elements and appliances-for example, halls, elevators, and boilers;

2. Negligence of maintenance personnel;

3. Failure to keep workmen's compensation in effect on project employees;

4. Failure to supervise pools, playgrounds, and similar areas where children congregate;

5. Violation of statutory duties, such as multiple dwelling laws, building codes, and fire department regulations;

6. Trespass or forcible entry and detainer, where a unit owner (or his lessee) is wrongfully disturbed or dislodged;

7. Automobile accidents involving vehicles owned by the condominium;

8. Products liability, where food, beverages, or detergents are dispensed by vending machines;

9. Injuries suffered in a garage, restaurant, recreation room, health club, or other facility operated by the group;

\footnotetext{
${ }^{3}$ See, e.g., 4 R. Poweli, Rest Property I 633.25 (1965); Kerr, Condominium-Statutory Implementation, 38 ST. Jorn's L. REv. I, 17 (1963); Berger, Condominium: Shelter on a Statutory Foundation, 63 Colum. L. Rev. 987, 995 (1963); Comment, Community Apartments: Condominium or Stock Cooperative?, 50 CALIF. L. Rev. 299, 312-I4 (1962).

"See, e.g., A. F. Rath, P. J. Grimes \& J. E. Moore, Strata Titres 35-36 (1962); Davis, Condominium and the Strata Titles Act, 9 Can. B.J. 469,486 (1966).
} 
I0. Miscellaneous exposures, such as nuisance, dangerous instrumentalities, nondelegable duties, subrogation, and indemnity agreements. ${ }^{5}$

The foregoing enumeration, which is far from exhaustive, indicates that sources of liability extend far beyond the limits of one's own conduct and care of his unit. While many statutes are worded in terms of delegating maintenance functions to the board of managers or managing agent, it is extremely doubtful that such provisions were intended to free unit owners of the duties which would normally attach to property owners and employers. ${ }^{6}$ The same is true of statutes which permit incorporation of the condominium association. Since the corporation would not own the realty, any liability stemming from ownership obligations would not be cut off. ${ }^{7}$ Again, courts may regard the corporate entity as a mere device for organizing the condominium's affairs, and not as a party in interest or functioning entity. ${ }^{8}$ This conclusion would be reinforced if the corporation were a mere shell, lacking capital or assets of consequence.

\section{B. Miscellaneous Statutory Approaches}

A minority of states have sought, with varying degrees of success, to immunize unit owners from all but their fractional share of any tort judgment rendered against the association. The statutes of Alaska ${ }^{9}$ and Washington ${ }^{10}$ require "all actions relating to the common areas and facilities for damages arising out of tortious conduct" to be brought against the association only. Any judgment obtained becomes a common expense. The Alaska statute explicitly provides that any unit owner may free himself of the lien by paying his proportionate share thereof (as determined by his undivided interest in the common elements). The same thought may be implicit in the portion of the Washington statute which makes tort judgments a common expense.

The Florida ${ }^{11}$ and Mississippi ${ }^{12}$ enabling acts stipulate that unit owners "have no personal liability for any damages caused by [the association] on or in connection with the use" of common elements. These statutes do provide, however, that a unit owner is liable for injuries occurring within his apartment to the same extent that the owner of a house would be. It is quite probable that these statutes do not completely exonerate the unit owner, and that procedurally a suit would be brought

\footnotetext{
${ }^{B}$ For the insurance coverage designed to meet similar exposures in housing cooperatives, see P. J. Rohian \& M. A. Reskin, Cooperative Housing: Law and Practice $\$$ I2.02 (1967).

- See 4 R. Powell, supra note 3, RT 633.24-.25.

${ }^{7}$ It should be noted that most of the enabling acts overcome the association's lack of an insurable interest by specific authorization for it to purchase a master casualty policy.

${ }^{8}$ Cf. Hathway v. Porter Royalty Pool, Inc., 296 Mich. 90, 295 N.W. 57 I (194I). One observer, however, has indicated that the condominium "association" may be considered an unincorporated association, with the usual legal consequences flowing from such a desgination. See Kerr, supra note 3, at $4 \mathrm{I}$.

${ }^{\circ}$ AlAs. Stat. \$ 34.07.260 (Supp. 1966).

${ }^{10}$ WAsH. Rev. CODE 564.32 .240 (Supp. I965).

${ }^{12}$ FLA. Stat. ANN. $\$ 71$ I.I8 (Supp. I966).

${ }^{12}$ Miss. Code ANN. $\$ 896-15$ (Supp. I966).
} 
against the association, which in turn would levy to pay the judgment. Thus viewed, a unit owner's exposure is not non-existent, but limited to the extent of his aliquot share of the levy (including loss of his unit if he does not meet the levy). ${ }^{18}$ The Virginia statute, ${ }^{14}$ although similar in purpose to the quoted provision, is somewhat obscure. It provides that a unit owner shall not be liable with respect to the negligence of any other co-owner, except insofar as the negligent party is acting for the council of co-owners. This may imply unlimited personal liability for the torts of management personnel. As for torts of single unit owners acting on their own account but involving common elements or facilities, the statute may mean there is no liability whatsoever on the part of fellow owners, or merely no liability until a judgment is made a common charge.

The Idaho provision ${ }^{15}$ specifies that a unit owner's liability for claims or judgments "arising out of or in connection with the ownership, use, operation or management of the common areas" is limited to the amount of such claim or judgment, times his undivided interest in the project. He may, however, compromise or settle his portion of such claim or judgment without prejudice to the judgment creditor, and without it constituting an admission or evidence against the unit owner. This provision may cause conflict among unit owners if the compromise authority is intended to apply both before and after the claim is reduced to a judgment. The Massachusetts provision ${ }^{16}$ is unique inasmuch as claims involving the common areas and facilities must be brought against the organization of unit owners, with the resulting judgment constituting a lien on common funds and property (and not on the realty as such). If these assets are insufficient, each unit owner is liable for a sum equal to the balance, times his percentage interest in the common elements. Michigan's enabling act merely provides that "suits against the co-owners shall be in the name of the condominium project."17 This may mean that unit owners must pay only their aliquot share of an assessment levied to pay a tort judgment. On the other hand, it could be interpreted as a procedural section, akin to that governing actions against partnerships, and not as a bar to unlimited personal liability for each unit owner. The final variation is found in the North Carolina statute ${ }^{18}$ to the effect that anyone "claiming damages for injuries without any participation by a unit owner shall first exhaust all available remedies against the Association of Unit Owners prior to proceeding against any unit owner individually." This provision is honey-combed with uncertainty. If a unit owner was personally negligent in connection with common elements or facilities, is the entire section inapplicable or is it only inapplicable to the negligent person? Must a judgment creditor levy

\footnotetext{
${ }^{13}$ For a more expansive view of the cited Florida statute, see 4 R. PownzL, supra note $3, \$ 633.25$. But see McCaughan, The Florida Condominitm Act Applied, I7 U. Fl. L. Rev, I, I8 (1964).

${ }^{14}$ VA. CoDE ANN. $\$ 55-79 \cdot 37$ (2) (Supp. Ig66).

${ }^{16}$ IDAHO CODE ANN. \$ 55-I5I5 (Supp. 1965).

${ }^{10}$ Mass. Gen. Laws ch. I83A, \$ I3 (Supp. 1966).

${ }^{17}$ Mich. Stat. ANN. $\$ 26.50$ (22) (Supp. 1965).

${ }^{18}$ N.C. Gen. Stat. \$47A-26 (I966).
} 
execution on the condominium in order to "exhaust" his remedies; and, if so, can a unit owner exonerate himself by paying his aliquot share of the judgment? Once the claimant exhausts his remedies, are all unit owners jointly and severally liable for the unpaid balance?

\section{Evaluation of Existing Approaches}

Ambiguities inherent in the language of specific statutory provisions have already been noted. In addition, most, if not all, of the cited measures are subject to more general criticisms, a few of which are set out below.

\section{The Type of Actions Covered}

Most of the cited measures apply only to tort claims arising out of management and control of common areas and facilities. This terminology should be replaced by language descriptive of all liabilities arising in connection with the condominium, except those for which an individual is alone responsible. "Ownership and maintenance of common areas" (or equivalent language) may not cover limited common elements-areas or facilities allocated to some but not all unit owners. ${ }^{19}$ Again, it may not be broad enough to include such sources of liability as non-delegable duties of property owners, respondeat superior, contractual indemnity claims of management personnel, trespass and forcible detainer, operation of community-owned vehicles, products liability, and injuries suffered by customers of restaurants or other commercial establishments on the premises. Lastly, uncertainty may occur in applying the statutory language in cases where all parts of the property are considered common elements, with the unit owner merely having title to the space he occupies. ${ }^{20}$

\section{Notice and Right to Counsel}

None of the statutes specifically provide for service of process upon, or right to counsel for, unit owners. ${ }^{21}$ This is so, despite the fact that actions against the association may result in a dollar loss or personal liability to such individuals (as, for ex-

\footnotetext{
${ }^{10}$ See Kerr, supra note 3 , at 27-3I.

${ }^{20}$ See 4 R. Powell, supra note 3, (91633.19-.29.

${ }^{22}$ Many enabling acts contain a provision modeled upon N.Y. Real Prop. Law $\$ 339$-dd (Mckinney Supp. 1967), which provides as follows:

"Actions may be brought or proceedings instituted by the board of managers in its discretion, on behalf of two or more of the unit owners, as their respective interests may appear, with respect to any cause of action relating to the common elements or more than one unit. Service of process on the unit owners in any action relating to the common elements or more than one unit may be made on the person designated in the declaration to receive service of process."

However, this brief paragraph leaves unresolved most of the questions raised in this paper on the subject of legal representation. For example, may the association's counsel (in all likelihood supplied by its carrier), represent the unit owners on that portion of the plaintiff's demand or settlement offer which exceeds the group's master liability insurance coverage? May counsel for an individual unit owner's insurance carrier also appear? Does a unit owner ever have a right to counsel of his own choosing when the condominium's owners are all made party defendants? Compare FLA. Stat. AnN. $\$ 711.12(2)$ (Supp. xg66), "Service of process upon the association shall not constitute service of process upon any unit owner."
} 
ample, where the master policy is insufficient in amount or does not cover the wrong in question). Moreover, such notification and right to be heard may be a prerequisite to the individual unit owner's claim against his own liability insurance carrier. Finally, lack of these safeguards would result in the anomalous situation that an active tortfeasor joined as a co-defendant would have a right to appear through counsel, whereas unit owners incurring derivative liability would not. Related questions concern the individual unit owner's right to compromise or settle in return for a general release, and the possible applications of res judicata and collateral estoppel. ${ }^{22}$

\section{The Status of the Errant Unit Owner}

None of the statutes clarify the position of the errant unit owner, the individual whose negligent or other tortious conduct led to the plaintiff's injury. It is probable that he may be sued individually or as co-defendant with the association of unit owners; in either case, his personal liability would be obtained. If the plaintiff only elects to sue the association, may the defendant or individual unit owners seek indemnity from the errant unit owner? Would the answer to this question vary with the amount and scope of the master liability policy-that is, with whether the loss was fully covered by insurance?

\section{The Effect of a Unit Owner's Failure to Pay His Aliquot Share of the Judgment}

Most of the cited enactments are unclear on the unit owner's position in the event he pays his aliquot share of the judgment but one or more fellow unit owners do not. If the judgment exceeds the value of the condominium development, or several unit owners do not meet their assessment, the plaintiff's judgment may remain partially unsatisfied. At this juncture, are the unit owners who have already contributed each personally liable for the balance, free of the debt altogether, or liable for a portion of the unpaid balance as re-assessed? If treated like any other common charge, there would be no bar to the unpaid balance being re-assessed. ${ }^{23}$

III

\section{The Unit Owner's Standing to Sue in Tort}

At this juncture the right of the unit owner to sue a fellow unit owner will be considered, followed by an analysis of his right of action, if any, against the association of unit owners. Finally, the rights of household members will be treated. In all three categories, the discussion proceeds on the assumption that the condominium's declaration and by-laws are silent on the subject, or contain restrictions upon suit which are unenforceable under local public policy. .

\footnotetext{
${ }^{22}$ Evidentiary questions, such as whether one co-owner's admissions bind the group as an admission against interest, also lurk in the background.

${ }^{23}$ See P. J. Rohan \& M. A. Reskin, Condominium: Law and Practice \$6.04 (1965). One statute, D.C. CODE ANN. $\$ 5-924$ (c) (r966), appears to bar such a re-assessment.
} 


\section{A. Actions Between Unit Owners}

There does not appear to be any question but that one unit owner can sue another in any case wherein the would-be defendant is the only party liable for the damage suffered. Intra-apartment negligence of a unit owner and trespass are illustrative of such causes of action. A more troublesome question is whether a unit owner may sue a fellow participant when the latter's action gives rise to tort liability on the part of the entire group (including the individual culprit). Thus, for example, may unit owner $A$ sue unit owner $B$ when the evidence discloses that $A$ fell over skates or a milkbox left in a darkened hallway by $B$ ? In most states, the absence of legislation on the point would seem to support the view that one unit owner could sue another under these circumstances. In the few states possessing statutory references to the subject, the answer is less clear. ${ }^{24}$ These provisions could be interpreted to mean that, in this situation, $B$ could not be sued by anyonem-whether or not a unit owner-and that the action would have to be brought against the group (on the ground that maintenance of common elements was at issue). The same legislation could also be read as requiring a plaintiff to elect between a suit against the individual wrongdoer and one against the condominium association. A more plausible interpretation is that such statutes only control liability of the group as coowners, and that one is free to join the individual wrongdoer and association as co-defendants in a single action (with the judgment binding each defendant jointly and severally). If these statutory hurdles are surmounted, the plaintiff unit owner may possibly be defeated by traditional negligence doctrines such as assumption of risk, contributory negligence and non-delegable duties of landowners. However, the applicability of these defenses would depend upon the facts of the particular case.

\section{B. Actions by a Unit Owner Against the Association}

The ability of one unit owner to sue his fellow unit owners as a group will be subject to all of the factors discussed in the preceding paragraph. In addition, there is the more general jurisprudential question whether the condominium enabling act (or the concept itself) abrogates the unit owner's right of action in connection with common areas and facilities. Implication of such a prohibition would reduce insurance premiums and disruptive lawsuits. ${ }^{25}$ At the same time, however, hundreds of unit owners (as in a retirement village) would be disenfranchised, perhaps without ever being aware of it. This seems far too serious a step to be founded upon implication. If suit is permitted, traditional tort principles such as non-delegable duties of a landowner, assumption of risk, contributory negligence, and related defenses may bar recovery. If this hurdle is surmounted, a question may arise as to whether the plaintiff must contribute to his own recovery; and here the answer appears to

\footnotetext{
${ }^{24}$ See statutes cited supra notes 6-23.

${ }^{25}$ This problem may be minimized through an educational program which brings home to the parm ticipants the fact that their premiums rise with the project's loss experience.
} 
be quite clearly affirmative. In the event a master policy were in effect, such a judgment would be covered if the plaintiff were not a named insured or, though a named insured, was nevertheless permitted to recover under the terms of the policy.

\section{Actions by Household Members}

Much of what has been already stated would govern the rights of members of a unit owner's household, at least to the extent that specific statutory provisions control tort actions against the condominium association in general. An owner's spouse would be in the same position as the unit owner, if the spouse's name appeared on the deed to the unit. Assuming that such is not the case, the troublesome question is whether any disabilities imposed upon a unit owner would be extended to members of his household. Here implication is stretched beyond the breaking point, and no such prohibition against suit could be implied from the existing legislative pattern. In the event the local condominium statute was deemed to bar suits by unit owners against the association, a hybrid situation might arise with respect to a wrongful death action growing out of a unit owner's demise. Here again, however, extension of the disability to the personal representative and next of kin of a unit owner would appear to require specific statutory authority. Query: Whether the "personal application" section of the F.H.A. Model Act and similar statutes would support an extension of a bar to suits to household members and guests?

\section{IV}

\section{Conclusions and Recommendations}

\section{$\therefore \quad$ A. 'The Role of Legislation and Administrative Regulations}

Varying legislative approaches are reflected in the condominium enabling acts, ranging from a bare outline of the subject to lengthy, definitive treatments. Similarly, the legislation of any one jurisdiction makes use of multiple drafting techniques. For example, some sections contain hard and fast rules; some sections, legislative judgments which may be altered by agreement; and still others, a mere enumeration of topics to be treated in each project's documentation. To this array may be added the device of entrusting matters of detail to regulations promulgated from time to time by the Attorney General's Office. Some combination of these tools should be brought to bear upon the problems discussed in this paper.

As a minimum, there should be legislative clarification of the condominium's authority to purchase a master liability policy covering every aspect of risk growing out of operation and concurrent ownership of the project. In this connection, it should be noted that most enabling acts contain specific authority for a master casualty policy covering the entire property (including privately owned areas). ${ }^{26}$ The absence of an

\footnotetext{
${ }^{20}$ Most carriers have limited the master policy to liability growing out of ownership and maintenance of the common areas and facilities. For a directive to this effect, issued in $x 963$ by the National Bureau .of Casualty Underwriters, see Rohan, Distuption of the Condominium Venture: The Problems of Casualty Loss and Insurance, 64 ColvM. L. Rev. 1045, 1081 n.229 (1964).
} 
equally broad provision relating to liability insurance may cause some insurance departments or carriers to conclude that similar liability policies lack legislative sanction. Finally, there should be clarification of the unit owner's liability in tort, his capacity to sue, the validity of covenants not to sue, the procedural steps in bringing an action against the association, and the mechanics of levying execution. The overall legislative pattern should be reinforced by formulation of master and unit-owner liability policies by state insurance departments, coupled with a requirement of complete disclosure of the tort and insurance picture in each project's offering plan.

\section{B. Specific Recommendations}

\section{Limited Liability Versus Adequate Insurance Coverage}

The principal difficulty in the tort area lies in the fact that each unit owner incurs unlimited liability in his capacity as co-owner of the project (and as employer of its management personnel). Should such a risk be attached to the negligible interest one may have in miles of commonly-owned roads or in multiple high-rise structures? Each unit owner's control over, or right to control, these elements is all but fictional. Moreover, the one exerting control (the managing agent) typically operates under protection of the group's promise to indemnify him in the event he is negligent. ${ }^{27}$. In a project of any size, the foregoing arrangement of rights and obligations is difficult to justify. The dilemma posed by the conflicting equities of injured parties and innocent unit owners might be resolved in one of two ways: limited liability for unit owners coupled with mandatory liability insurance coverage, or creation of an adequate, air-tight insurance program. Each solution will be considered in turn.

The limited liability approach has the merit of simplicity and certainty. ${ }^{28}$ Moreover, it safeguards the unit owner against unexpected liability through a gap in insurance coverage. Also on the plus side, this approach would place the unit owners on a par with counterparts residing in cooperative housing. In such a venture, liability is centered upon the corporate landowner, with each participant merely running the risk that an uninsured liability would result in loss of the property. Nevertheless, all the factors to be considered in weighing limited liability do not point. in a single direction. Thus, if such a limit were decreed, it would be impractical to: apply it to large projects and not to small ones. Hence, all condominiums would be given a benefit denied to concurrent owners generally. The cooperative analogy does not meet this objection, because the condominium's common elements are owned individually and not by a corporation. Again, if liability were to be limited, just what acts would be so privileged and where would that limit be drawn. Would the unit owner who caused the common liability be so exempt? Would the unit

\footnotetext{
${ }^{37}$ See, e.g., condominium declarations set forth in P. J. RowAN \& M. A. Reskin, supra note 23, App. C.

${ }^{28}$ Both of these factors would be required to enable a layman to grasp the rights and obligations he is acquiring when he purchases a condominium unit. Complicated liability and insurance provisions would also detract from the condominium's usefulness as a method of supplying home ownership for low income families.
} 
owner's exposure be restricted to loss of his unit or to his pro rata share of the judgment (measured by his undivided interest in the project)? Finally, there would be the problem of fashioning mandatory liability insurance coverage to guarantee that injured members of the public would be fully compensated despite individual liability limitations.

If the limited liability solution is passed over, in favor of increased insurance protection, still other problems must be faced. Is it feasible to write a master policy covering every aspect of unit owner liability in connection with the condominium project, including intra-apartment negligence? If it is possible to draft such a policy, there is the further question whether it is wise to write coverage in this fashion. Should the group pay premiums to cover negligent conduct of individual participants in their own units? Under the prevailing practice, condominiums acquire an "Owner's, Landlord's and Tenant's" policy covering liability arising out of the common elements. ${ }^{29}$ Individual unit owners must purchase separate policies to cover negligence dissociated with the property and intra-apartment liability. As previously indicated, however, this two-fold approach to insurance is not tailored to the condominium's needs and may lead to conflicts, excess premiums, or worse, gaps in coverage.

In the writer's view, the best approach to the problem would consist of the following: (I) A statutory requirement that each condominium acquire and keep in force a master liability policy covering all risks faced in common by all condominium unit owners; (2) a provision in the master policy covering the liability of any individual unit owner for acts or omissions in connection with the condominium, including intra-apartment negligence. ${ }^{30}$ Premiums for the latter coverage could be allocated to the individual participant to avoid inequities; ${ }^{31}$ (3) include the managing agent as an insured party or otherwise cover the unit owners' indemnification agreement; (4) restrict unlimited liability to a unit owner's personal conduct. Where liability is imposed on all unit owners and the insurance in effect is inadequate, limit each participant's liability to his pro rata share of the unpaid judgment (as determined by his undivided interest in the project). In this connection, there should be no additional liability for uncollected portions of the judgment-that is, unpaid segments should not be re-assessed against the remaining unit owners; (5) where the plaintiff complains of negligence giving rise to the liability of all unit owners, suits should be directed against the association and defended by that organiza-

\footnotetext{
${ }^{29}$ For the coverage acquired by individual unit owners, see the directive of the National Bureau of Casualty Underwriters, in Rohan, supra note 26.

${ }^{30}$ The condominium's participants share the risk of a member's negligence under a master casualty policy. Are the differences between their casualty and liability problems so great as to preclude common coverage of the latter? If a truly master liability policy cannot be formulated, it may be helpful at least to have the same carrier issue both master and unit liability policies, or to take other steps to avoid troublesome issues of contribution, subrogation, and legal representation.

${ }^{31}$ N.Y. REAI PrOP. LAW $\$ 339$-bb (McKininey Supp. 1967) authorizes disproportionate charges to reflect variations in insurance costs as between different units. Query whether this section would have to be enlarged to authorize different charges based on the loss experience of each owner?
} 
tion. Notice of the pending litigation should be given to all unit owners; however, the right to participate through counsel should be restricted to cases wherein a unit owner's personal, unlimited liability is sought. ${ }^{32}$ Where a unit owner's personal liability is sought in addition to that of the group, the plaintiff should be permitted to join both as party defendants. ${ }^{33}$ Thereafter, execution should be allowed against the individual, but limited against the association (to the pro rata levy device discussed above). The levy, of course, should allocate a fraction of the common liability to the unit owner who is personally liable, rather than spreading the liability solely over his fellow unit owners; (6) subrogation of the carrier to claims against individual unit owners should be prohibited. ${ }^{34}$

\section{Capacity to Sue}

Since condominium unit owners will not control common areas in any realistic sense, and in view of the enormous size of these projects (compared to earlier forms of concurrent ownership, including cooperatives), the writer is of the opinion that unit holders should be permitted to sue the group in negligence. Although the participants, as co-owners, are ultimately responsible for the property's condition, they are more akin to proprietary lessees and should be given the same right to sue the organization charged with day-to-day maintenance. ${ }^{35}$ Accordingly, it is suggested that the enabling statutes be amended to authorize such suits and to require that the association's liability policies specifically provide coverage for unit owner suits. The mechanics of such a provision could be handled in one of two ways. The legislation could stipulate that a unit owner may sue the association in tort, as if the individual were a member of the public, and that such suits will not be barred on the ground that the plaintiff is a concurrent owner. In the alternative the statute could provide that, for purposes of a suit in tort by a unit owner, the condominium's common elements, facilities, and personnel shall be deemed to be within the exclusive control of the association. Under either approach, the plaintiff would remain subject to the defenses of contributory negligence and assumption of risk (stemming from his conduct and not mere ownership of his interest in the project).

If the position advocated herein is rejected, the legislature may bar unit owner tort suits by a specific provision. It then must decide whether the ban extends to household members, servants, guests, and lessees. A decision must also be reached on how to handle wrongful death actions and minors. A middle-of-the-road position may

\footnotetext{
${ }^{32}$ Attention should also be given to the individual representation question in situations where the plaintiff's demand or settlement offer exceeds the master liability policy.

ss $T$ There is no sound reason for eliminating the personal liability of the individual wrongdoer.

see Ellman, Fundamentals of Condominium and Some Insurance Problems, 1963 INs. L.J. 733, 738 $\left(\mathrm{Ig} 6_{3}\right)$.

${ }^{36}$ The same factors support the writer's contention that the liability of unit owners in connection with common elements and facilities should be limited. Additional risks, both of injury and of liability, will be present when a condominium consists of mixed units (commercial and residential), bringing more members of the public onto the premises and exposing them (and the unit owners) to greater dangers than those associated with residential uses.
} 
consist of permitting the condominium's documentation to control, through adoption of one of several legislatively approved alternatives. Among the latter might be a limitation upon such suits in the form of: (a) a requirement that all such claims go to arbitration; (b) a ceiling upon recoveries, either in terms of a dollar amount or actual out-of-pocket expenses; or (c) a prohibition against recoveries in excess of the group's liability insurance coverage. If any one or more of these controls are imposed, additional directives would have to be supplied to cover the unit owner's right to sue managerial personnel or the managing agent (to prevent circumvention of the previously imposed restrictions).

Many more questions than answers are supplied in this article. This is to be expected in an area where so little has been written and experience is still limited. It is to be hoped, however, that most of these problems can be resolved through the swift action of legislatures, insurance departments, and interested liability carriers. Otherwise full utilization of the condominium as a housing tool may not be attained. 